\title{
"OMG! You Said What in Class? TMI!" College Student and Professor Perceptions of Professional Etiquette Violations
}

\author{
Heide D. Island \\ College of Arts and Sciences, Pacific University, United States
}

Copyright $\mathrm{C} 2016$ by authors, all rights reserved. Authors agree that this article remains permanently open access under the terms of the Creative Commons Attribution License 4.0 International License

\begin{abstract}
This study sampled undergraduate students and faculty from a small, Pacific Northwest, Liberal Arts University using an online survey of attitudes and behavior regarding professional etiquette in the classroom. It was anticipated that students and faculty would report significant differences in their perceptions of what constitute professional behavior violations, potentially contributing to problems with classroom rapport, communication, and ultimately poor student preparation for employment. However, the results suggest that students and professors' perceptions of socially civil behavior in the classroom are more congruent than disparate. What differs is likely the definitions of what behaviors are formal and acceptable across contexts than simply in the classroom or a professional context.
\end{abstract}

Keywords Professional Etiquette, Employability Skills, Professionalism, Millennials

\section{Introduction}

By almost every economic indicator (e.g., employment rate, quit rate, bankruptcies, poverty rate, etc.) with the exception of education, Millennials are struggling compared to their older counterparts [1]. Millennials or Generation Y, the cohort of Americans born between 1980 and the mid-2000s, are the largest U.S. generation, representing one-third of the total population [2]. They are also the most educated of any generation in history, 34 percent of Millennials have at the very least a bachelor's degree [3]. In spite of their education, Millennials are also the largest unemployed group in the United States [4]. In June of 2016, the U.S. unemployment rate fell to just 4.9 percent, the lowest it has been since 2008 [5] and yet, 40 percent of the unemployed are Millennials [4]. In addition, among 18 to 29 year olds, 8 percent are unemployed [1].

It should come as no surprise then that employment and career advancement are at the fore of Millennials' reasons for attending college. In a survey of almost 200,000 college freshmen from 283 four-year U.S. universities, 87.9 percent cited, "to get a better job" as their primary reason for attending college [6]. Similarly, The Chronicle of Higher Ed in a survey of freshmen from 2015 reported the top seven most important reasons for attending college as: to get a better job (85\%); learn about things that interest them (82\%); train for a specific career $(76 \%)$; gain a general education and appreciation of ideas (72\%); to make more money (70\%); to prepare for professional or graduate school (59\%); and to develop into a more cultured person (49\%) [7]. The value of college in spite of increased costs of tuition, student debt, and higher rent, is not inconsequential. According to the Pew Research Center [8], Millennial college graduates consistently outperform their less educated peers in job attainment, career advancement and in annual income. But the Generation Y employee is also less likely to stay employed and less likely to find a job matched to their education, earning potential, or their interests [9].

Further complicating the issues of employment and occupational availability, several studies investigating job performance and employer satisfaction found that Millennials have a perception problem. For example, in a study of employer satisfaction with recent college graduates, Millennials were perceived as a flight risk [9], less invested in their jobs, therefore more likely to seek a better bargain at an alternate company [10]. The Association of American Colleges and Universities [11] asked employers and college students a series of questions pertaining to employment preparation, consistently students believed they were better prepared for the job market than their employers, with problem-solving, communication, team work and social skills emerging as the greatest preparation disparities. This is a problem since a survey of over 400 employers across the United States cited professionalism, work ethic, oral and written communication skills, teamwork and collaboration, problem-solving, creativity and resourcefulness as some of the most important employability skills for career success [12]. 
Poor employability skills, particularly in the area of professionalism are also cited in a number of multidisciplinary studies as one of the chief complaints among college faculty in mentoring their students [13-17]. At closer inspection, issues of collaboration, social skills, and good judgement [12] are all part of a broader construct of etiquette, or social civility. So this begs the question, what is etiquette in the digital age, when texting is commonplace, intelligent phones are an accessory to the fork at the dinner table, and email, Instagram, Facebook, Snapchat, and Twitter are available in every context? Although etiquette has a number of definitions, several elements appear to be universal and certainly applicable in a professional context, these include: Civility (e.g., mutual respect, consideration of behavioral intention, adherence to social norms) [15], Accountability (e.g., taking responsibility for mistakes), Polish (e.g., hygiene, editing written and oral communication), Preparation, and Punctuality [12]. However, there is a good deal of disagreement within the empirical literature of what constitutes etiquette and professionalism. Similarly, this definitional disparity occurs across students and faculty as well. This is particularly troublesome given employers cite professionalism and collaboration (i.e., etiquette), work ethic, oral and written communication skills, and problem-solving, as most important employability skills [12]. Thus, professional etiquette is inextricably linked to employability and yet, in today's digital age of seeking immediate answers for virtually any question the expert and thereby the authority is deconstructed. This means many of the rules of etiquette, the known clichés to help guide behavior, "respect your elders" (or those with authority), "don't speak until spoken to" (including the patience to wait for someone to finish speaking before interjecting), "behave as a guest in someone else's house" (or simply recognizing others' personal boundaries both in space and in language), "don't forget the pleases and thank yous" (including follow-up letters of gratitude), and "if you can't say something nice, don't say anything at all" (or inappropriate statements) implicitly depend on the proximity to, and interaction of, the . Yet as a culture, we spend much of our time communicating in isolation, through online blogs, text messages, Twitter feeds, email or through the most rudimentary, an approximation of a gesture, the culturally specific emoji for the "thumbs" up gesture. This contributes to the variability of contexts in which behavior might occur, as well the formality, and complexity of the implicit social norms within each of those contexts. Consequently, contemporary definitions of etiquette, not to mention professional behavior, career-specific etiquette, is unclear, in part due to generational differences in these expectations.

The purpose of this study was to examine the extent to which these definitions of etiquette differ between faculty and students. If students or faculty believe the only relevant tutelage is content knowledge and not the inclusion of professional development, like employability skills, this outs a fundamental flaw in our college curricula. Professional etiquette, is one of the fundamental employability skill cited among professionals and employers. If one of the goals of a college education is career and employment preparation, we need to do a better job of educating students of what these expectations and professional norms are and how to avoid violating them.

\section{Materials and Method}

\subsection{Participants}

Survey participants were recruited from a sampling pool of undergraduate students and professors from the United States. The sample frame involved social media (e.g., Facebook), email solicitation, and snowball sampling. In both samples of students and faculty, females comprised the majority of respondents with $80 \%(n=72)$ of the students $(N=90)$ and $69 \%(n=29)$ of the faculty $(N=42)$ with a total number of 132 respondents. The average age of students was 20.5 years, while few professors provided their age; thus the average age of faculty could not be calculated.

\subsection{Materials}

Published academic research of professional etiquette and employability skills provides no single validated, empirical, or contemporary (i.e., included appropriate use of technology and social media) measure either individually or as a comprehensive survey of the two constructs: professional behavior (i.e., etiquette) or employability skills (both content-specific and experiential). Consequently, we mined the empirical literature for relevant measures that might be used in an initial analysis of attitudes concerning both professional etiquette and employability skills. As a result, three published measures of technology use [13], communication formality [14], and classroom civility [15] were adapted to better understand student and faculty attitudes of appropriate behavior and how technology-use may moderate perceptions of professional behavior.

The technology-use measure provided both quantitative response questions as well as qualitative response questions. For the quantitative questions, texting frequency was measured using a 5-point Likert-based response scale (e.g., never to daily) while the qualitative questions asked participants to give examples of classes in texting most occurred and if there were professor variables that contributed to the ease or probability of texting. Similar questions were posed for social media, including frequency and contextual use (e.g., classroom, meetings, during presentations, outside of the professional arena).

The adapted survey of social incivilities $[13,15]$ also used a quantitative Likert-based 5-point agreement scale pertaining to attitudes and behavior as well as questions requiring examples of unprofessional behavior both among professors and students as well introspective questions asking participants to outline their own professional challenges. 
Qualitative questions from a netiquette survey [14] assessed how formality of correspondence (e.g., email and texting) influenced attitudes of professional behavior. Additional demographic questions were included (e.g., age, gender) as well as participants' ranking of communication formality (i.e., "Which mode of communication is more formal? Texting, emailing, telephoning...?"), and how they perceived texting, social media, email, or surfing the internet when they were in class, meetings, or during presentations and qualitative questions requiring examples of what they perceived were unprofessional behavior. The resulting collection of questions used for this paper included 80 quantitative Likert-based and qualitative responses.

\subsection{Design and Procedure}

This study involved descriptive research using SurveyMonkey, a web-based survey distribution and data collection software. Participants were invited to participate in an online attitude and behavioral survey about professional etiquette. The survey began with informed consent procedures, data collection began following the acknowledgement and agreement of the informed consent procedures and a willingness to participate by checking a consent box and clicking an execute button labeled, "Begin" to administer the survey.

\section{Results}

In order to assess student and faculty attitudes about appropriate behavior, we needed to establish how each perceived violations of appropriate behavior. Given the literature has focused largely on incivility in the classroom [18] as an antecedent for professional incivility, we started with classroom professional behavior.

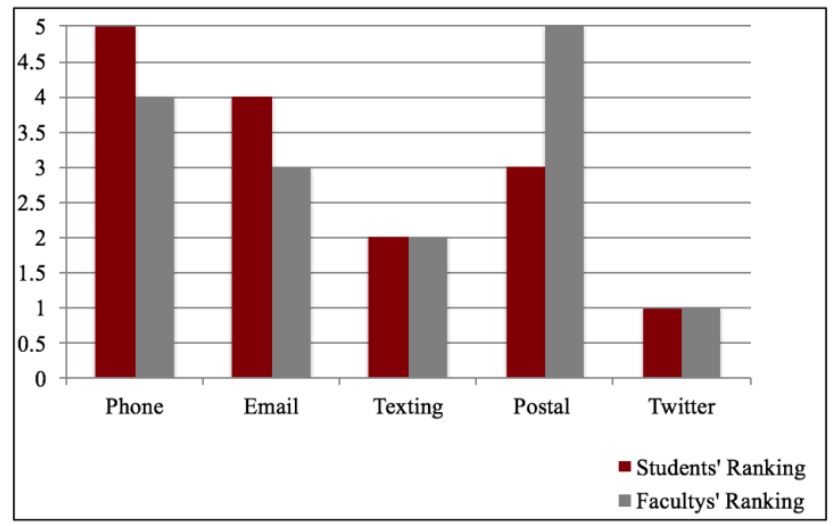

Figure 1. Correspondence Formality Rankings by Student and Professor

First, we evaluated perceptions of different types of correspondence as formal or informal. Although students and faculty agreed that Twitter and texting were the least formal form of correspondence and thereby less professional, their perception of telephone, email, and postal communication differed (see Figure 1). Students ranked telephone correspondence as the most formal, followed by electronic mail and postage; while faculty ranked postal correspondence as the most formal, followed by telephone communication, and email.

Further students and faculty were asked to take the perspective of the other regarding social norm expectations in class. This perhaps, more than any other component of the results, illustrates the civility confusion between professors and their students. For example, students, recognized that faculty find texting rude, yet among themselves, students did not perceive in-class texting as inappropriate (see Figure 2).

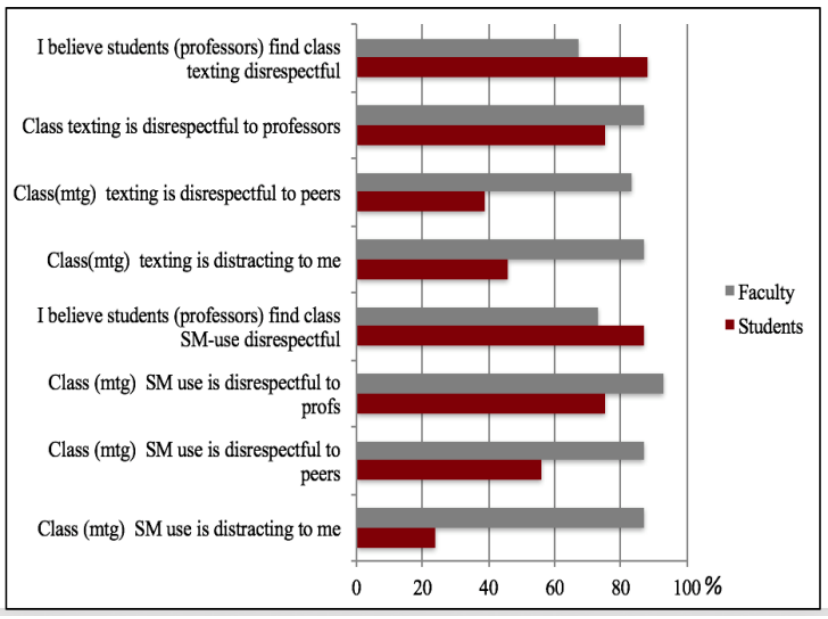

Figure 2. Faculty and Student Attitudes About In-Class Texting and Social Media Use

This may explain the differences between professors and students in their level of embarrassment when social media alerts, telephones ring, text or email alerts go off during meetings, classes, or presentations. Faculty reported $(M=3.93 ; \quad S D=.26) \quad$ feeling significantly more embarrassment if their cell phone rang during a class or presentation, relative to students $(M=2.66 ; S D=.60)$, $t(102)=12.44 ; p<.01, \delta=.60$. Of course, faculty felt that students were more likely to violate civil classroom behavior (i.e., no texting, emailing, or use of social media) if the professors were less liked than their peers. In fact, when prompted to provide their agreement with the statement, "students text more in classes of professors they don't like," faculty ( $M=2.28 ; S D=.75)$ reported significantly higher agreement than the students (i.e., "I text more in classes of professors I don't like"), $(M=2.00 ; S D=.67)$, $t(108)=-5.09, \quad p<.01, \quad \delta=.20$. Similarly, professors felt students were more likely to violate professional etiquette in the classes they liked less $(M=2.77 ; S D=.99)$, relative to students' self-reported probabilities of texting, emailing, checking Facebook, or tweeting in all of their classes $(M=2.13 ; S D=.71), t(108)=-5.38, p<.01, \delta=.22$.

Even though, professional etiquette is most certainly an employability skill, professors underestimated the importance of applying their content courses to career 
success or employability $(M=1.98 ; S D=.70)$ relative to the students $(M=2.13 ; S D=.71) t(108)=-7.36, p<01, \delta=.21$, who assigned such skills a very high rating for their classes. But one problem may also be that faculty do not necessarily appreciate their role in mentoring for job success or the fallibility of their own professional etiquette. Thus we asked students to generate a list of what they felt were the most egregious violations of professional behavior among professors (see Figure 3).

\begin{tabular}{|c|c|c|}
\hline & Student List $(N=90)$ & Faculty List $(N=42)$ \\
\hline 1 & $\begin{array}{l}\text { Professor fails to return materials in } \\
\text { within a reasonable window of time } \\
(n=54)\end{array}$ & Student is disrespectful. $(n=32)$ \\
\hline 2 & Professor fails to respond to email. $(n=49)$ & $\begin{array}{l}\text { Student expects accommodation for } \\
\text { late material }(n=29)\end{array}$ \\
\hline 3 & $\begin{array}{l}\text { Professor appears unprepared for class. } \\
(n=45)\end{array}$ & $\begin{array}{l}\text { Student texts or checks social media } \\
\text { during class. }(n=24)\end{array}$ \\
\hline 4 & $\begin{array}{l}\text { Professor is condescending toward } \\
\text { students. }(n=44)\end{array}$ & $\begin{array}{l}\text { Student appears unprepared for class. } \\
(n=22)\end{array}$ \\
\hline 5 & $\begin{array}{l}\text { Professor makes an error in lecture and } \\
\text { does not acknowledge it. }(n=34)\end{array}$ & Student is tardy to class. $(n=22)$ \\
\hline 6 & Professor is tardy to class. $(n=30)$ & $\begin{array}{l}\text { Student sends an email without } \\
\text { proofreading it. }(n=13)\end{array}$ \\
\hline
\end{tabular}

Note: Participants could select more than one behavior.

Figure 3. Top Six Most Unprofessional Classroom or Instructional Behaviors Reported by Students and Faculty

Six factors emerged, though these can be distilled into three broad categories: punctuality (in returning graded materials and in attendance), respect (acknowledgement and mutual respect), and accountability (acknowledge when they make a mistake. One of the most valued professorial professional behaviors was timeliness in returning graded materials. Not surprisingly, students rated grading punctuality higher $(M=3.25 ; S D=.95)$ than did professors $(M=2.09 ; S D=.70), \mathrm{t}(122)=-7.44 ; p<.00, \delta=.05$. Students felt on average, that 5 days $(S D=2.06)$ was an acceptable timeframe for reading, critiquing and grading exams, while papers should be returned after 6 days $(S D=.2 .65)$; beyond that was an unreasonable delay. In contrast, professors felt on average, that one week from the examination was an appropriate window to read, review, and return $(S D=3.06)$, $t(122)=-3.37 ; p=.001, \delta=.11$. For papers, 8 to 10 days was on average, an acceptable return time $(S D=3.56), t(122)=-2.94$; $p=.004, \delta=.08$.

Faculty were asked to generate a similar transgression list pertaining to student professional etiquette violations. Similarly, six behaviors emerged (see Figure 3) all within the same global behaviors of punctuality (punctual to class), mutual respect (no class disruption with social media), and accountability (accept consequences for late material), though also with a four category of conscientiousness (e.g., proofreading and class preparation).

Since there was agreement between both faculty and students in terms of what they felt were troublesome violations of professional conduct, we asked students and professors to report their own professional challenges (see
Figure 4).

The introspective challenges faculty most rated as problematic were consistent with the students' number one rated unprofessional behavior among their professors failure to return graded materials on time. Although students also rated time management as their greatest professional challenge. Though among professors highest rated professional etiquette violation by students, time management was only implicitly suggested as a lack of preparation for class. Both students and faculty listed proof-reading emails as the third most problematic professional etiquette challenge. Students listed attitude, truancy and tardiness as problems as well, while faculty felt they both overshared in class and accommodated too many questions during class (likely more of a global problem of losing classroom control).

\begin{tabular}{|c|c|c|}
\hline & Student List $(N=90)$ & Faculty List $(N=42)$ \\
\hline 1 & $\begin{array}{l}\text { Budgeting time for assignments. } \\
(n=53)\end{array}$ & Budgeting time for grading. $(n=28)$ \\
\hline 2 & Consistent studying. $(n=49)$ & Arriving to meetings on time. $(n=7)$ \\
\hline 3 & Proofreading Emails. $(n=10)$ & Proofreading Emails. $(n=22)$ \\
\hline 4 & Attitude. $(n=8)$ & Over-sharing during class. $(n=12)$ \\
\hline 5 & Arriving to class on time. $(n=15)$ & Coming to class on time. $(n=8)$ \\
\hline 6 & Truancy. $(n=6)$ & $\begin{array}{l}\text { Accommodating too many } \\
\text { questions during class. }(n=16)\end{array}$ \\
\hline
\end{tabular}

Note: Participants could select more than one behavior.

Figure 4. Most frequently Self-Reported Professional Challenges Among Students and Faculty

\section{Conclusions}

The purpose of this study was to evaluate the definitional disparities between faculty and students of what constitutes professional etiquette and their associated violations. Based on the results of this initial survey of professor and student attitudes, the most cited unprofessional behaviors for both groups include four broad violation categories: tardiness, accountability, respect, and conscientiousness. Tardiness may refer to attendance, failing to make a meeting, class, or appointment on time, but it may also include failing to make a deadline. For professors, students most frequently cited failing to read, review, and return graded materials in a timely manner as their most troubling and common unprofessional behavior. Professors cited student entitlement as a particularly problematic professional violation, specifically in an unwillingness to accept consequences for failing to meet a deadline and also expecting an accommodation or extension for late work. Students referred to professional violations of accountability in the form of pride, a failure to acknowledge a mistake in lecture or errors in written material as particularly bothersome violations of professional courtesy. 
Further, both students and faculty listed a lack of respect as a significant violation of professional civility. For students, this was evidenced through professor condescension, among faculty, they felt disrespected through inappropriate use of social media, texting, disrupting class, verbal transgressions, and unauthorized use of internet in their classes. As an aside, students reported an awareness that faculty did not appreciate this behavior, but among themselves, students did not believe this use of technology in the classroom was rude. Finally, faculty uniquely listed failures in conscientiousness as particularly problematic among their students' professional etiquette, as well as a challenge for themselves. An example of this is in proofreading emails, taking the time to make sure they lack errors or are appropriately formal.

Overall, there were fewer disparities in student and professors' perception of professional etiquette violations. Though, there were differences in the perception of what constitutes formal and therefore more appropriate communication (e.g., emailing, in person, or texting). No doubt the convenience and availability of texting, emailing, "Googling" the Internet, checking social media, and even taking notes through photographing an overhead, PowerPoint slide, or the notes written on a whiteboard contributes to this discrepancy. Generational differences are also a likely contributor, just like language and social norms, etiquette both social and professional evolve across the generations, as the availability of resources and our historical experiences change.

Despite the small sample size and the measurement constraints (there were no standardized empirical measures of professional etiquette specifically for college students) cof this study, it was apparent that professional etiquette not only involves attitudes and behaviors but also potentially a temperamental advantage associated with conscientiousness. Although several studies in the health professions like nursing [19], surgery [20], physical therapy [21], pharmacy [22], argue for the inclusion of professionalism in their graduate curricula, much of this work involves patient care and is less applicable to a college and general employment setting. Other literature [23] investigating differing professionalism perceptions among students, faculty and employers are now largely dated with the frenetic pace of technology innovation and adoption among college-age pre-professionals and the changing expectations and skillsets necessary for employment.

In addition, consistent with The Chronicle of Higher Education's report of college freshmen in 2015 [7], the student participants for this study rated career preparation and employability skills as not simply a course expectation, but as an important component of their college experience. Faculty however, underestimated the importance of career and employment preparation, although this may be attributable to the sampling frame of Liberal Arts professors.

Professional etiquette as a learning construct is a bit ubiquitous, with no singular outcome measure (i.e., proficiency in a content area for a class) yet it is maintained as definitive expectation among employers and professors. This means, professional etiquette, as an employability skill is an implicit expectation, without clear instruction or responsibility of who is charged with the tutelage.

It is clear from this study and the paucity of measures available to evaluate professional etiquette that a need exists for such an instrument. Therefore, the development of a formal, validated psychometric measure of professional etiquette as a subcategory of a more global construct of employability skills is in process. The inception of the Professional Etiquette and Employability Skills Inventory (PEESI) is a multidisciplinary project that solicited feedback from an array of professional disciplines including: law, medicine, consulting, technology, health and wellness, and retail, as well as from college faculty and students. The goal is to establish an empirically valid outcome measure that might evaluate initial scores of professional etiquette (e.g., civility attitudes and behavior) and employability skills (e.g., conflict resolution, problem-solving, and communication) at the onset of their college career that can be tracked and compared to concluding scores upon graduation.

The value of mentoring professional and social etiquette in college is evident, it does not appear to be enculturated elsewhere, as such professors need to think of professionalism as a learning outcome for all of their syllabi. In fact, Feldman [24] asserts that classroom civility is an instructor responsibility to engender socially responsible adults not simply for career advancement but world betterment.

\section{Acknowledgements}

The author is grateful to the participants who agreed to participate in this initial professional etiquette project as well as Devin Furutani, Austin Downey and Bryce Harris for their initial work on the SurveyMonkey materials.

\section{REFERENCES}

[1] Generation Opportunity. State of the Millennial Report: A review of the challenges and opportunities for young Americans. Arlington, VA, 5-10, Dec. 12, 2016.

[2] Council of Economic Advisors. The Millennial Report 2014. The Executive Office of the President of the United States. Washington, D.C., 23-25, October 2014

[3] E. Patten, R. Fry. How Millennials today compare to their grandparents 50 years ago. Pew Research Center, March 19, 2015.

[4] L. Goodman. Millennial college graduates: Young, educated, and jobless. Newsweek, May 27, 2015. 
[5] U.S. Bureau of Labor Statistics. Online Available: http://data.bls.gov/timeseries/LNS14000000

[6] J. H. Pryor, K. Eagan, L. B. Hurtado, S. Berdan, M. H., Case. The American Freshman: National norms Fall 2012. Los Angeles, CA: Higher Education Research Institute, UCLA, 2012.

[7] Chronicle of Higher Education, Almanac, 2016-17: A profile of freshman at 4 year colleges, Fall 2015. Chronicle of Higher Education, 82 (43), 34-35, August 19, 2016.

[8] P. Taylor, R. Fry, R. Oats. The rising cost of not going to college. Pew Research Center. Online Available: http://www.pewsocialtrends.org/files/2014/02/SDT-higher-e d-FINAL-02-11-2014.pdf

[9] National Chamber Foundation. The Millennial Generation, Research Review, 22-26, 2012.

[10] K. L. Campana, J. J. Peterson. Do bosses give extra credit? Using the classroom to model real-world work experience. College Teaching, 61, 60-66, 2013.

[11] S. Jaschik. Study finds big gaps between student and employer perceptions. Higher Education, January 20, 2015. Available Online: https://www.insidehighered.com/news/2015/01/20/study-fin ds-big-gaps-between-student-and-employer-perceptions?wid th $=775$ \& height $=500$ \&iframe $=$ true

[12] J. Casner-Lotto, L. Barrington. Are they really ready to work? Employers' perspectives on the basic knowledge and applied skills of new entrants to the $21^{\text {st }}$ Century U.S. Workforce. Partnership for $21^{\text {st }}$ Century Skills, 17-53, 2006.

[13] D.R. Tindell, R.W. Bohlander. The use and abuse of cell phones and text messaging in the classroom: A survey of college students. College Teaching, 60, 1-9, 2012.

[14] K. K. Stephens, M. L. Houser, R. L. Cowan. R U able to meat me: The impact of students' overtly casual email messages to instructors. Communication Education, 58 (3), 303-326, 2009.

[15] H.C. Alberts, H. D. Hazan, R. B. Theobald. Classroom incivilities between college students and instructors in the US. Journal of Geography in Higher Education, 34 (3), 439$462,2010$.

[16] S. Hirshy, J. M. Braxton. Effects of student incivilities on students. New Directions for Teaching and Learning, 99, 6776, 2004.

[17] K. L. Campana, J. J. Peterson. Do bosses give extra credit? Using the classroom to model real-world work experience. College Teaching, 61, 60-66, 2013.

[18] W. L. Bjorklund, D. L. Rehling. Student perceptions of classroom incivility. College Teaching, 58, 15-18, 2010.

[19] F. Dagenais, A. I. Meleis. Professionalism, work ethic, and empathy in nursing: The nurse self-description form. Western Journal of Nursing Research, 4 (4), 407-422, 1982.

[20] M. S. Hochberg, A. Kalet, S. Zabar, E. Kachur, C. Gillespie, R. S. Berman. Can professionalism be taught? Encouraging evidence. The American Journal of Surgery, 199, 86-93, 2010 .

[21] D. U. Jette, L. G. Portney. Construct validation of a model for professional behavior in physical therapy students. Physical Therapy, 83 (5), 432-443, May 2003.

[22] D. P. Hammer. Professional attitudes and behaviors: The "A's and B's" of professionalism. American Journal of Pharmaceutical Education, 64 (Winter), 455-463, 2000.

[23] A. Hall, L. Berardino. Teaching professional behaviors: Differences in perceptions of faculty, students and employers. Journal of Business Ethics, 63, 407-415, 2006.

[24] F. J. Feldman. Classroom Civility is another of our instructor responsibilities. College Teaching, 49 (4), 137-140, 2001. 